\title{
HUBUNGAN PENGETAHUAN, SIKAP, DAN MOTIVASI DENGAN KEPATUHAN KONSUMSI TABLET BESI FOLAT PADA IBU HAMIL
}

\author{
Widya Budiarni, Hertanto Wahyu Subagio*) \\ Program Studi Ilmu Gizi Fakultas Kedokteran Universitas Diponegoro \\ Jl.Dr.Sutomo No.14, Semarang, Telp (024) 8453708, Email : gizifk@undip.ac.id
}

\begin{abstract}
Background: The benefit of giving free iron folic tablets to prevent iron deficiency anemia in pregnancy is often inhibited by the compliance of iron folic tablets consumption in pregnant women. Compliance is a behavior that can be influenced by many factors, such as knowledge, attitude and motivation. The purpose of this study is to determine association between knowledge, attitude, and motivation with compliance of iron folic tablets consumption in pregnant women.

Methods: This is a cross sectional study, with 56 pregnant women as sample which are selected by consecutive sampling in Halmahera health center, Semarang. Data of compliancy on iron folic tablets consumption was measured by tablet calculation. Data of knowledge, attitude and motivation are taken from interviews using questionnaire. Bivariate analysis performed by Rank Spearman test.

Results: This study showed 41,1\% of subjects complied iron folic tablet consumption. The average compliance of iron folic tablet consumption in 10 days is $62.86 \%$. Majority of pregnant women have a good knowledge (50\%), good attitude (51.8\%) and good motivation (57.1\%). This study showed association between knowledge $(r=0.370$, $p=0.005)$, attitude $(r=0.343, p=0.010)$, and motivation $(r=0.616, p=0.000)$ with compliance of iron folic tablets consumption.

Conclusion: Motivation is the most dominant factor. The higher the motivation given the more compliance the pregnant women of taking iron folic tablets consumption.
\end{abstract}

Keywords: Knowledge; attitudes; motivation; compliance; iron folic supplementation; pregnant women

\begin{abstract}
ABSTRAK
Latar Belakang: Manfaat pemberian tablet besi folat secara gratis untuk pencegahan anemia defisiensi besi pada kehamilan sering dihambat oleh kepatuhan ibu hamil dalam mengkonsumsi tablet besi folat. Kepatuhan merupakan perilaku yang dapat dipengaruhi oleh faktor dari dalam diri individu yaitu pengetahuan, sikap dan motivasi. Tujuan penelitian ini adalah untuk mengetahui hubungan pengetahuan, sikap dan motivasi ibu hamil dengan kepatuhan mengkonsumsi tablet besi folat.

Metode: Penelitian cross sectional ini dilakukan di Puskesmas Halmahera Kota Semarang dengan sampel 56 ibu hamil yang dipilih secara consecutive sampling. Data kepatuhan mengkonsumsi tablet besi folat diperoleh melalui perhitungan tablet. Data pengetahuan, sikap dan motivasi diperoleh dari wawancara menggunakan kuesioner. Analisis bivariat dilakukan dengan uji Rank Spearman.

Hasil: Hasil penelitian menunjukkan 41,1\% ibu hamil patuh mengkonsumsi tablet besi folat. Rata-rata kepatuhan mengkonsumsi tablet besi folat dalam 10 hari adalah 62,86\%. Sebagian besar ibu hamil memiliki pengetahuan baik (50\%), sikap baik (51,8\%) dan motivasi baik (57,1\%). Penelitian ini menunjukkan ada hubungan pengetahuan ( $r=$ $0,370 ; p=0,005)$, sikap $(r=0,343 ; p=0,010)$, dan motivasi $(r=0,616 ; p=0,000)$ dengan kepatuhan mengkonsumsi tablet besi folat.
\end{abstract}

Simpulan: Motivasi merupakan faktor yang paling dominan berhubungan dengan kepatuhan mengkonsumsi tablet besi folat. Semakin tinggi motivasi semakin patuh ibu hamil mengkonsumsi tablet besi folat.

Kata Kunci: Pengetahuan; sikap; motivasi; kepatuhan; suplementasi tablet besi folat; ibu hamil

\section{PENDAHULUAN}

Anemia merupakan masalah kesehatan yang sering dijumpai di negara berkembang, termasuk di Indonesia. Salah satu penyebab anemia adalah defisiensi zat besi. Anemia defisiensi zat besi sering terjadi pada ibu hamil. Defisiensi zat gizi mikro lain seperti vitamin A, folat, seng dan tembaga turut memiliki peranan terhadap terjadinya anemia pada kehamilan.,2

Berdasarkan data WHO (1993-2005), prevalensi anemia ibu hamil di dunia sebesar $41,8 \%$. Prevalensi anemia yang tinggi terdapat pada ibu hamil di Afrika yaitu 55,8\% dan 41,6\% di Asia. ${ }^{3}$ Ibu hamil ras hitam lebih berisiko

${ }^{*}$ Penulis Penanggungjawab 
mengalami anemia dibandingkan dengan ras putih. ${ }^{4}$ Menurut Riset Kesehatan Dasar (RISKESDAS) 2007, prevalensi anemia ibu hamil di Indonesia sebesar 24,5\%. ${ }^{5}$ Hasil survei anemia pada ibu hamil di 15 kabupaten/kota di Jawa Tengah tahun 2007 menunjukkan bahwa prevalensi anemia ibu hamil adalah $57,7 \%{ }^{6}$

Anemia defisiensi zat besi pada ibu hamil akan berdampak pada besarnya angka kesakitan dan kematian maternal, angka kesakitan dan kematian janin serta risiko terjadinya berat bayi lahir rendah. ${ }^{2}$ Risiko timbulnya anemia defisiensi besi dapat dicegah apabila ibu hamil dapat memenuhi kebutuhannya akan zat besi. Kebutuhan zat besi ibu hamil mengalami peningkatan hingga $1070 \mathrm{mg}$ karena mutlak dibutuhkan janin dan plasenta. ${ }^{7}$ Jumlah kebutuhan zat besi yang banyak ini menyebabkan ibu hamil berisiko tinggi defisiensi besi. Pemenuhan zat besi dari makanan yang masih kurang dapat dilakukan dengan suplementasi besi. ${ }^{2,7,8}$

Pencegahan anemia defisiensi besi telah lama dilakukan di Indonesia. Salah satu pencegahannya melalui program suplementasi besi dan asam folat pada ibu hamil dengan melaksanakan pemberian tablet besi folat secara gratis. Namun, manfaat pemberian tablet besi folat ini sering dihambat oleh kepatuhan ibu hamil dalam mengkonsumsi tablet besi folat. Kepatuhan dalam mengkonsumsi tablet besi folat merupakan salah satu faktor yang dianggap paling berpengaruh dalam keberhasilan program suplementasi besi selain penyediaan tablet besi dan sistem distribusinya. ${ }^{9}$ Keberhasilan program pencegahan anemia sangat tergantung pada partisipasi masyarakat yang berdasar pada analisis perubahan perilaku yang berupa penilaian pengetahuan, sikap dan praktek yang ada di masyarakat. ${ }^{10}$ Perilaku timbul karena adanya dorongan dari dalam diri manusia yang disebut motivasi. ${ }^{11}$ Oleh karena itu, selain pengetahuan dan sikap, motivasi juga berpengaruh terhadap perilaku.

Penelitian yang dilakukan di delapan negara berkembang mengungkapkan salah satu faktor yang mempengaruhi kepatuhan dalam mengkonsumsi tablet besi adalah pengetahuan mengenai tablet besi folat. ${ }^{12}$ Selain itu, penelitian mengenai sikap ibu hamil di Palestina mengungkapkan bahwa ibu hamil yang memiliki sikap yang baik, akan mengerti pentingnya memeriksaan diri ke pelayanan kesehatan dan mengkonsumsi tablet besi. ${ }^{13}$ Kepatuhan tinggi dalam mengkonsumsi tablet besi juga karena motivasi untuk pencapaian kesehatan yang lebih baik setelah mengkonsumsi tablet besi folat. ${ }^{14} \mathrm{Hal}$ ini karena motivasi merupakan dorongan yang digunakan untuk memulai dan mengarahkan perilaku.

Berdasarkan uraian tersebut, peneliti tertarik untuk meneliti hubungan antara pengetahuan, sikap dan motivasi ibu hamil dengan kepatuhan mengkonsumsi tablet besi folat.

\section{METODE PENELITIAN}

Penelitian ini dilakukan pada ibu hamil yang periksa kehamilan di Puskesmas Halmahera Kota Semarang. Penelitian ini merupakan penelitian gizi masyarakat dengan desain cross sectional yang dilaksanakan pada bulan Mei-Juni 2012. Berdasarkan perhitungan korelasi didapatkan sampel sebanyak 56 sampel yang kemudian dipilih secara consecutive sampling. Kriteria inklusi dalam penelitian ini adalah ibu hamil trimester II dan III yang mendapatkan tablet besi folat dan bersedia menjadi subjek penelitian. Variabel dependen dalam penelitian ini adalah kepatuhan mengkonsumsi tablet besi folat pada ibu hamil, sementara pengetahuan, sikap, dan motivasi ibu hamil merupakan variabel independen.

Kepatuhan mengkonsumsi tablet besi folat merupakan tingkat konsumsi tablet besi folat pada ibu hamil dalam kurun waktu 10 hari. Ibu hamil trimester II dan III yang memeriksakan diri ke puskesmas memperoleh tablet besi folat antara 1015 tablet. Kepatuhan diukur dari persentase perhitungan jumlah tablet besi folat yang dikonsumsi dibandingkan dengan jumlah tablet besi folat yang seharusnya dikonsumsi ibu hamil. Ibu hamil dikatakan patuh jika skor $\geq 90 \%$, apabila skor $<90 \%$ dikatakan tidak patuh mengkonsumsi tablet besi folat. ${ }^{15}$

Pengetahuan ibu hamil merupakan pengetahuan mengenai tablet besi folat dan anemia defisiensi besi yang diukur dari persentase skor jawaban benar berdasarkan kuesioner yang terdiri dari 13 pertanyaan. Skor yang diperoleh dikelompokkan menjadi kategori pengetahuan yaitu pengetahuan baik jika skor $>80 \%$, pengetahuan sedang jika $60-80 \%$ dan pengetahuan kurang jika $<60 \%$. $^{16}$

Sikap merupakan pendapat terhadap pernyataan mengenai tablet besi folat. Motivasi merupakan dorongan yang diikuti dengan kesadaran dan kemauan untuk mengkonsumsi tablet besi folat tanpa terpengaruh adanya efek samping tablet besi folat. Pengukuran sikap dan motivasi dilakukan dengan menggunakan 
kuesioner yang sebelumnya telah dilakukan uji validitas. Skor yang didapat kemudian dihitung dengan menggunakan skala Likert yang berarti skor pada setiap pertanyaan merupakan rating yang kemudian dijumlahkan untuk semua pertanyaan. Pertanyaan pada kuesioner sikap dan motivasi terdiri dari pertanyaan favorable dan unfavorable. Jumlah pertanyaan kuesioner sikap dan motivasi masing-masing terdiri dari 13 pernyataan. Pertanyaan sikap yang favorable jika setuju mendapat skor 3, ragu-ragu 2, tidak setuju 1 dan pernyataan yang bersifat unfavorable diberi nilai kebalikan dari favorable. Pertanyaan motivasi diukur dengan 4 kategori yaitu selalu mendapat skor 4, sering 3, jarang 2, tidak pernah 1 untuk pertanyaan favorable dan pertanyaan yang bersifat unfavorable diberi nilai kebalikan dari favorable. Penilaian skor sikap dan motivasi menggunakan
skor-T. Pengelompokan sikap yaitu sikap baik jika $\geq$ mean skor-T dan sikap kurang baik jika < mean skor-T. Pengelompokan motivasi yaitu motivasi baik jika $\geq$ mean skor-T dan motivasi kurang baik jika $<$ mean skor-T. ${ }^{17}$

Analisis univariat untuk mendeskripsikan data karakteristik subjek, kepatuhan, pengetahuan, sikap, dan motivasi. Uji kenormalan yang dilakukan menggunakan Kolmogorov Smirnov menunjukkan bahwa data yang berdistribusi normal hanya terlihat pada variabel motivasi sehingga analisis bivariat yang digunakan untuk melihat hubungan antar variabel dilakukan dengan uji korelasi Rank Spearman.

\section{HASIL PENELITIAN \\ Karakteristik subjek}

Tabel 1. Karakteristik subjek berdasarkan usia, trimester, dan pendidikan

\begin{tabular}{lcc}
\hline \multicolumn{1}{c}{ Karateristik } & Frekuensi & Persentase (\%) \\
\hline Usia & & \\
\hline a. $\quad$ 20 tahun & 7 & 12,5 \\
b. 20 - 30 tahun & 35 & 62,5 \\
c. >30 tahun & 14 & 25 \\
\hline Usia Kehamilan & & 42,9 \\
\hline a. Trimester II & 24 & 57,1 \\
b. Trimester III & 32 & \\
\hline Pendidikan & & 3,6 \\
\hline a. Tidak Sekolah & 2 & 7,1 \\
b. SD & 4 & 14,3 \\
c. SMP & 8 & 71,4 \\
d. SMA/SMK & 40 & 1,8 \\
e. Akademi & 1 & 1,8 \\
f. Universitas & 1 & \\
\hline
\end{tabular}

Pada penelitian ini, usia subjek mayoritas berkisar antara $20-30$ tahun. Usia terendah subjek 18 tahun dan tertinggi 38 tahun. Usia kehamilan sebagian besar subjek berada pada trimester III.
Pendidikan terakhir sebagian besar subjek adalah SMA/SMK. Pendidikan tertinggi subjek adalah Universitas.

Tabel 2. Distribusi subjek menurut pengetahuan, sikap, motivasi, dan kepatuhan mengkonsumsi tablet besi folat

\begin{tabular}{lcccccc}
\hline \multirow{2}{*}{ Kategori } & \multicolumn{2}{c}{ Patuh } & \multicolumn{2}{c}{ Tidak Patuh } & \multicolumn{2}{c}{ Total } \\
\cline { 2 - 7 } & $\mathrm{n}=23$ & $\%$ & $\mathrm{n}=33$ & $\%$ & $\mathrm{~N}=56$ & $\%$ \\
\hline Pengetahuan & & & & & & \\
Baik & 17 & 73,9 & 11 & 33,3 & 28 & 50 \\
Sedang & 6 & 26,1 & 18 & 54,6 & 24 & 42,9 \\
$\quad$ Kurang & 0 & 0 & 4 & 12,1 & 4 & 7,1 \\
\hline Sikap & 17 & 73,9 & 12 & 36,4 & 29 & 51,8 \\
Baik & 6 & 26,1 & 21 & 63,6 & 27 & 48,2 \\
$\quad$ Kurang baik & &
\end{tabular}




\begin{tabular}{lcccccc}
\hline Motivasi & & & & & & \\
Baik & 21 & 91,3 & 11 & 33,3 & 32 & 57,1 \\
Kurang baik & 2 & 8,7 & 22 & 66,7 & 24 & 42,9 \\
\hline
\end{tabular}

Berdasarkan hasil penelitian $41,1 \%$ subjek patuh dalam mengkonsumsi tablet besi folat. Median kepatuhan konsumsi tablet besi folat $70 \%$ $\pm 33,01$ dengan nilai kepatuhan terendah $0 \%$ dan tertinggi $100 \%$. Sebagian besar subjek yang patuh memiliki pengetahuan sedang hingga baik, sikap dan motivasi yang baik. Sebanyak $50 \%$ subjek memiliki pengetahuan dalam kategori baik. Median pengetahuan subjek mengenai anemia defisiensi besi dan tablet besi folat $80,76 \% \pm 14,11$ dengan nilai pengetahuan terendah 38,46 dan tertinggi 100 . Sebanyak $73,9 \%$ subjek yang patuh memiliki pengetahuan yang baik sedangkan 54,5\% subjek yang tidak patuh memiliki pengetahuan sedang. Sebanyak $73,9 \%$ subjek memiliki sikap dalam kategori baik. Median sikap 52,92 \pm 10 dengan nilai skor-T sikap terendah 26,69 dan tertinggi 62,77 . Sebanyak $73,9 \%$ subjek yang patuh memiliki sikap yang baik dan $63,6 \%$ subjek yang tidak patuh memiliki sikap yang kurang baik terhadap tablet besi folat. Sebanyak 91,3\% subjek memiliki motivasi kategori baik. Mean motivasi 50 \pm 10 dengan nilai skor-T terendah 23,88 dan tertinggi 63,65. Penggunaan mean dilakukan karena data berdistribusi normal. Sebanyak 91,3\% subjek yang patuh memiliki motivasi baik sedangkan $66,7 \%$ subjek yang tidak patuh dalam mengkonsumsi tablet besi folat memiliki motivasi kurang baik.

Tabel 3. Distribusi subjek menurut media konsumsinya

\begin{tabular}{llc}
\hline Konsumsi & Frekuensi & Persentase (\%) \\
\hline a. Air putih & 38 & 67,8 \\
b. Air gula & 1 & 1,8 \\
c. Susu & 1 & 1,8 \\
d. Teh & 7 & 12,5 \\
e. Pisang & 9 & 16,1 \\
\hline
\end{tabular}

Tabel 4. Distribusi subjek menurut efek samping yang dialami dan alasan lain yang menyebabkan ketidakpatuhan dalam mengkonsumsi tablet besi folat

\begin{tabular}{|c|c|c|c|c|c|c|}
\hline & Patuh & $\%$ & $\begin{array}{l}\text { Tidak } \\
\text { Patuh }\end{array}$ & $\%$ & $\begin{array}{l}\mathrm{N} \text { dari } \\
\text { total }\end{array}$ & $\begin{array}{l}\% \text { dari } \\
\text { total }\end{array}$ \\
\hline \multicolumn{7}{|l|}{ Efek Samping } \\
\hline Mual & 7 & $30,4 \%$ & 22 & $66,7 \%$ & 29 & $51,8 \%$ \\
\hline Diare & 0 & $0 \%$ & 0 & $0 \%$ & 0 & $0 \%$ \\
\hline $\begin{array}{l}\text { Perubahan } \\
\text { warna tinja }\end{array}$ & 1 & $4,3 \%$ & 10 & $30,3 \%$ & 11 & $19,6 \%$ \\
\hline Konstipasi & 5 & $21,7 \%$ & 13 & $39,4 \%$ & 18 & $32,1 \%$ \\
\hline \multicolumn{7}{|l|}{ Alasan lain } \\
\hline Bosan & 0 & $0 \%$ & 4 & $12,1 \%$ & 4 & $7,1 \%$ \\
\hline Lupa & 1 & $4,3 \%$ & 2 & $6,1 \%$ & 3 & $5,4 \%$ \\
\hline $\begin{array}{l}\text { Rasa dan bau } \\
\text { tablet }\end{array}$ & 7 & $30,4 \%$ & 20 & $60,6 \%$ & 27 & $48,2 \%$ \\
\hline Malas & 9 & $39,1 \%$ & 12 & $36,4 \%$ & 21 & $37,59 \%$ \\
\hline
\end{tabular}

Berdasarkan penelitian diketahui $51,8 \%$ subjek mengalami efek samping mual yang berakibat pada ketidakpatuhan. Penyebab ketidakpatuhan lainnya adalah karena konstipasi dan perubahan warna tinja menjadi hitam. Alasan lain yang terungkap dari $48,2 \%$ subjek yaitu fisiologis tablet yang berarti tablet memiliki rasa tidak enak dan bau amis, selain itu subjek juga merasa bosan, lupa dan malas untuk mengkonsumsi tablet besi folat.

Hubungan antara Pengetahuan, Sikap dan Motivasi dengan Kepatuhan 
Diagram 1 menunjukkan terdapat hubungan bermakna antara pengetahuan dengan kepatuhan mengkonsumsi tablet besi folat $(\mathrm{p}=$ $0,005 ; \mathrm{r}=0,370)$, nilai $\mathrm{r}$ menunjukkan bahwa pengetahuan yang baik belum cukup membuat ibu hamil patuh mengkonsumsi tablet besi folat.
Diagram 2 menunjukkan terdapat hubungan yang bermakna antara sikap dengan kepatuhan mengkonsumsi tablet besi folat $(\mathrm{p}=0,010 ; \mathrm{r}=$ 0,343 ), nilai $\mathrm{r}$ menunjukkan bahwa sikap yang baik belum cukup membuat ibu hamil patuh mengkonsumsi tablet besi folat.

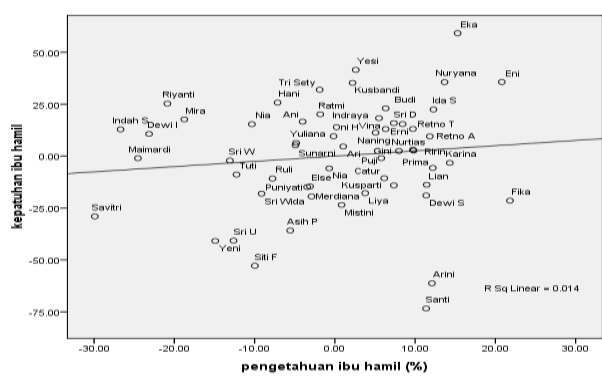

Diagram 1.

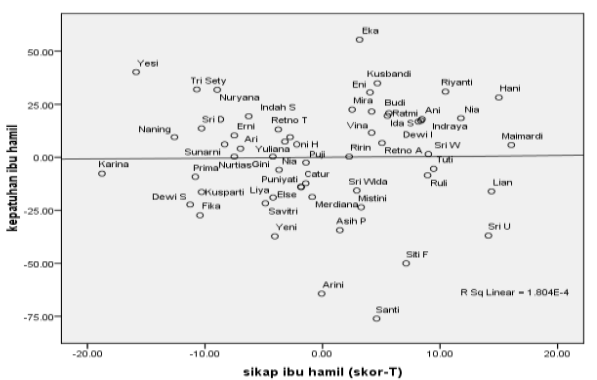

Diagram 2.

Diagram 3 menunjukkan terdapat hubungan yang bermakna antara motivasi dengan kepatuhan mengkonsumsi tablet besi folat $(\mathrm{p}=$

$0,000 ; \mathrm{r}=0,616)$. Nilai $\mathrm{r}$ menunjukkan bahwa semakin baik motivasi semakin patuh ibu hamil mengkonsumsi tablet besi folat.

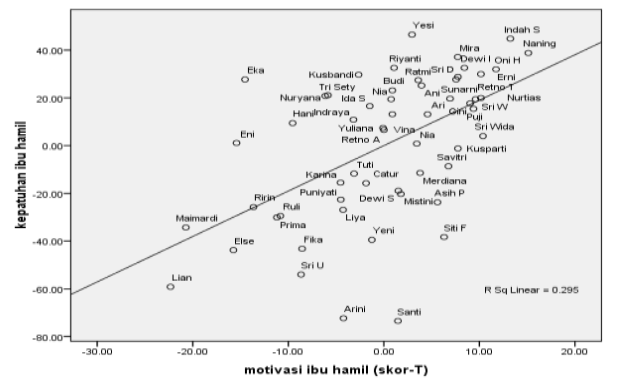

Diagram 3

\section{PEMBAHASAN}

Pada penelitian ini, $62,5 \%$ subjek memiliki usia berkisar antara 20-30 tahun. Usia reproduksi yang optimal bagi ibu hamil adalah antara 20-35 tahun karena rahim dan bagian tubuh lainnya sudah siap untuk menerima kehamilan. ${ }^{2}$ Sebanyak $57,1 \%$ subjek memiliki usia kehamilan trimester III. Pada trimester ini, kecukupan zat besi sangat diperlukan selain untuk mencukupi kebutuhan ibu dan janin juga untuk persalinan. ${ }^{7}$ Sebanyak $71,4 \%$ subjek memiliki pendidikan terakhir SMA/SMK. Pendidikan akan mempengaruhi ibu hamil dalam memilih dan mengevaluasi sesuatu yang baik untuk kesehatan diri dan kehamilannya.

Pengindraan seseorang melalui penglihatan dan pendengaran akan menghasilkan suatu pengetahuan. Pengetahuan diperoleh dari proses belajar yang dapat membentuk keyakinan tertentu sehingga seseorang berperilaku berdasarkan keyakinannya. ${ }^{18}$ Pada penelitian ini,
92,9\% ibu hamil memiliki pengetahuan dalam kategori sedang hingga baik. Berdasarkan data yang diperoleh dari kuesioner, pengertian anemia, gejala anemia, pencegahan anemia, dan manfaat tablet besi folat untuk penambah darah sebagian besar subjek sudah mengetahui. Namun, terdapat subjek yang menganggap penyakit kurang darah dengan penyakit darah rendah adalah sama sehingga subjek yang memiliki tekanan darah tinggi tidak berani mengkonsumsi tablet besi folat. Ibu hamil juga hanya mengerti manfaat tablet besi folat untuk penambah darah sehingga masih terdapat ibu hamil yang mengkonsumsi tablet besi folat hanya ketika ibu hamil merasa lelah. Hal ini mengungkapkan bahwa banyak ibu hamil yang belum mengerti mengenai dampak anemia defisiensi besi khususnya terhadap kejadian berat bayi lahir rendah.

Hasil analisis menunjukkan bahwa terdapat hubungan yang bermakna antara 
pengetahuan dengan kepatuhan mengkonsumsi tablet besi folat. Hal ini sesuai dengan hasil penelitian Susilawati bahwa ada hubungan antara pengetahuan dengan kepatuhan mengkonsumsi tablet besi folat. ${ }^{19}$ Pengetahuan berhubungan dengan kepatuhan karena pengetahuan merupakan domain yang sangat penting untuk terbentuknya perilaku. Perilaku akan langgeng jika didasari oleh pengetahuan. Pengetahuan yang diperoleh melalui pengindraan ibu hamil terhadap informasi kesehatan selama kehamilan akan berpengaruh terhadap perilaku ibu hamil dalam menjaga kesehatannya. ${ }^{18}$

Sikap merupakan respon tertutup seseorang terhadap objek tertentu yang dapat menggambarkan suka atau tidak suka. Sikap seseorang terhadap suatu objek menunjukkan pengetahuan orang tersebut terhadap objek yang bersangkutan. ${ }^{17}$ Semakin baik pengetahuan maka akan semakin positif sikap yang terbentuk. Hasil penelitian menunjukkan 51,8\% subjek memiliki sikap yang baik. Pada penelitian ini ditemukan faktor yang mendasari terbentuknya sikap diantaranya pengetahuan, pengalaman pribadi, dan orang lain yang dianggap penting seperti petugas kesehatan.

Hasil penelitian menunjukkan ada hubungan antara sikap dengan kepatuhan. Hal ini sesuai dengan penelitian di Surakarta bahwa terdapat hubungan antara sikap tentang anemia dengan keteraturan mengkonsumsi tablet besi folat pada ibu hamil. ${ }^{20}$ Hubungan sikap dengan kepatuhan diduga karena adanya pemahaman yang baik mengenai anemia defisiensi besi dan tablet besi folat dan pengalaman subjek terhadap kehamilan. Selain itu, terdapat 3 komponen pokok yang memegang peranan penting dalam menentukan sikap seseorang yaitu kepercayaan atau keyakinan, kehidupan emosional dan kecenderungan untuk bertindak. ${ }^{17}$ Pada penelitian ini, berdasarkan nilai $\mathrm{r}(0,343)$ dapat diketahui bahwa sikap yang baik belum cukup membuat ibu hamil patuh. Hal tersebut dimungkinkan karena kurangnya kepercayaan atau keyakinan subjek terhadap tablet besi folat sehingga timbul kecenderungan subjek yang belum sepenuhnya mendukung terhadap konsumsi tablet besi folat.

Motivasi adalah keinginan dalam diri seseorang yang mendorongnya untuk berperilaku. ${ }^{18}$ Pada penelitian ini $57,1 \%$ subjek memiliki motivasi yang baik. Berdasarkan data yang diperoleh, motivasi baik dalam mengkonsumsi tablet besi folat karena keinginan untuk mencegah anemia dan menjaga kesehatan ibu dan janin.
Namun keinginan ini hanya pada tahap anjuran petugas kesehatan, bukan atas keinginan diri sendiri sehingga ketidakpatuhan seringkali terjadi karena ibu hamil lupa. Selain itu, adanya efek samping juga mempengaruhi motivasi yang berakibat pada ketidakpatuhan mengkonsumsi tablet besi folat.

Hasil penelitian menunjukkan bahwa ada hubungan yang kuat antara motivasi dengan kepatuhan artinya semakin baik motivasi maka semakin patuh ibu hamil mengkonsumsi tablet besi folat. Ada hubungan antara motivasi dengan kepatuhan karena motivasi merupakan kondisi internal manusia seperti keinginan dan harapan yang mendorong individu untuk berperilaku agar mencapai tujuan yang dikehendakinya. ${ }^{18}$ Semakin dekat dengan tujuan maka semakin kuat motivasi seseorang karena motivasi dapat menimbulkan semangat untuk mempercepat pencapaian kepuasan. ${ }^{21}$

Kepatuhan mengkonsumsi tablet besi folat merupakan perilaku dimana ibu hamil mendukung program suplementasi besi yang dilakukan pemerintah untuk mencegah anemia pada ibu hamil. Pada penelitian ini, ketersediaan tablet besi folat sudah baik artinya ibu hamil yang memeriksakan dirinya di Puskesmas Halmahera memperoleh tablet besi folat secara gratis. Hasil penelitian ini menunjukkan 58,9\% ibu hamil tidak patuh dalam mengkonsumsi tablet besi folat.

Ketidakpatuhan terjadi karena ibu hamil merasa mual akibat rasa dan bau tablet. Selain itu, tablet besi folat yang dikonsumsi setiap hari menimbulkan rasa bosan sehingga seringkali ibu hamil lupa dan malas untuk mengkonsumsinya. Hal ini serupa dengan hasil penelitian di Yogyakarta yang mengatakan bahwa alasan yang menyebabkan ketidakpatuhan yaitu rasa dan bau tablet, malas, bosan dan lupa. ${ }^{22}$ Penelitian di Malaysia juga mengungkapkan lupa dan efek samping sebagai alasan ibu hamil tidak patuh mengkonsumsi tablet besi folat. ${ }^{23}$

$$
\text { Pencegahan anemia dengan }
$$

mengkonsumsi tablet besi folat memang memberikan efek samping yang tidak menyenangkan. Efek samping tablet besi folat meliputi nyeri lambung, mual, konstipasi, dan diare yang dijumpai pada $15-20 \%$ konsumen. ${ }^{6,24,25}$ Pada penelitian ini, 66,07\% subjek mengalami minimal satu efek samping tablet besi folat. Terdapat 3 subjek yang memiliki nilai kepatuhan 0\% dikarenakan efek samping tablet yang tidak dapat ditoleransi. Selain itu, diketahui sebanyak $67,9 \%$ subjek mengkonsumsi tablet besi folat 
bersamaan dengan air putih, lainnya dengan pisang, teh, susu, dan air gula. Konsumsi tablet besi folat bersamaan dengan teh akan menghambat penyerapan zat besi hingga $60 \% .{ }^{26}$ Hasil penelitian mengungkapkan subjek yang mengkonsumsi tablet besi folat selain bersamaan dengan air putih bertujuan untuk mengurangi rasa dan bau tablet yang tidak enak. Masih terdapatnya ketidakpatuhan cara mengkonsumsi tablet besi folat turut menambah alasan penyebab tingginya anemia.

\section{KETERBATASAN PENELITIAN}

Penelitian ini merupakan penelitian bersama yang dilakukan oleh 2 orang sehingga mungkin terdapat kesamaan pada beberapa data dengan penelitian yang dilakukan oleh Febriana Rahmawati dengan judul Kepatuhan Konsumsi Tablet Besi Folat pada Ibu Hamil dan Faktor yang mempengaruhi.

\section{SIMPULAN}

Hasil penelitian menunjukkan bahwa motivasi merupakan faktor yang paling dominan berhubungan dengan kepatuhan mengkonsumsi tablet besi folat. Semakin baik motivasi semakin patuh ibu hamil mengkonsumsi tablet besi folat.

\section{SARAN}

1. Sehubungan dengan masih rendahnya angka kepatuhan maka pemberian konseling perlu dilakukan untuk memberi informasi mengenai dampak anemia defisiensi besi terkait dengan kejadian berat bayi lahir rendah dan perbedaan antara penyakit kurang darah dengan penyakit darah rendah, membantu ibu hamil dalam menangani masalah efek samping yang timbul akibat dari mengkonsumsi tablet besi folat serta memberi motivasi dalam upaya meningkatkan kepatuhan.

2. Perlu dilakukan penelitian lebih lanjut untuk menemukan faktor lain yang berhubungan dengan kepatuhan mengkonsumsi tablet besi folat pada ibu hamil.

\section{UCAPAN TERIMA KASIH}

Terima kasih penulis sampaikan kepada responden di Puskesmas Halmahera Kota Semarang, petugas bagian KIA, dan karyawan lain serta kepala Puskesmas Halmahera Kota Semarang yang telah banyak membantu dalam pengambilan data untuk penelitian ini. Penulis juga mengucapkan terima kasih kepada Prof.dr.H.M.Sulchan,M.Sc,DA Nutr,Sp.GK dan
dr.Yekti Wirawanni selaku penguji atas kritik dan saran untuk perbaikan artikel.

\section{DAFTAR PUSTAKA}

1. Hertanto WS. Anemia dan status gizi mikro pada ibu hamil. Jurnal Kedokteran Media Medika Indonesiana FK Undip. 2005; 40(3). Available at http://www.mediamedika.net/archives/69 [Accessed on April 20, 2012].

2. Arisman MB. Gizi dalam daur kehidupan. Jakarta: Buku Kedokteran EGC. 2004. p.151-152.

3. McLean E, Cogswell M, Ines Egli, Daniel Wojdyla, Bruno de Benoist. Worldwide prevalence of anaemia, WHO vitamin and mineral nutrition information system, 1993-2005. Public Health Nutr 2009; 12: 444-54.

4. Adebisi OY, Gregory S. Anemia in pregnancy and race in the United States: Black at risk. Fam Med 2005; 37(9): 655-662.

5. Badan Penelitian dan Pengembangan Kesehatan Departemen Kesehatan RI. Riset Kesehatan Dasar 2007. Jakarta. 2008. Available at http://www.ppid.depkes.go.id [Accessed on April 27, 2012].

6. Dinas Kesehatan Provinsi Jawa Tengah. Profil Kesehatan 2007. Available at http://www.dinkesjatengprov.go.id [Accessed on Feb 19, 2012].

7. Ramakrishnan U, Kunsch BI. Anemia and iron deficiency in developing countries. In: Lammi CJ, editors. Handbook of nutrition and pregnancy. USA: Humana Press. 2008. p.3-9.

8. Erick M. Nutrition during pregnancy and lactation. In: L. Kathleen Mahan, Sylvia Escott-Stump. Krause's food and nutrition therapy. $12^{\text {th }}$ ed. Canada: Saunders Elsevier. 2008. p.160-184.

9. Maryani, I Made Alit, Siti Helmyati. Sistem distribusi dan cakupan suplementasi tablet besi ibu hamil pasca bencana tsunami 2004 di Kabupaten Aceh Besar Provinsi Nanggroe Aceh Darussalam. IJCN 2006; Volume 3 Nomor 1. Available at http://www.jcn.or.id/v2 [Accessed on Feb 13, 2012].

10. De Maeyer EM. Pencegahan dan pengawasan anemia defisiensi besi. Alih bahasa: Arisman MB. Jakarta: Widya Medika. 1993. p.24-29.

11. Shannon RJ. Motivational interviewing: enhancing patient motivation for behavior change. In: International Handbook of Occupational Therapy Interventions. New York: Springer Science. 2009. p.515-523

12. Galloway R, Erin D, Leslie E, et al. Women's perceptions of iron deficiency and anemia prevention and control in eight developing countries. Social Science \& Medicine 2002; 55: 529-44.

13. Amani WM. Iron deficiency anemia among pregnant women in Nablus District; prevalence, 
knowledge, attitude and practices. Nablus: AnNajah National University. 2007.

14. Seck BC, Jackson RT. Determinants of compliance with iron supplementation among pregnant women in Senegal. Public Health Nutr. 2008; 11(6): 596605.

15. Bongga DC, Ordenes MAC. Factors influencing compliance with iron supplementation among pregnant woment. Social Science Diliman 2006. 3; 84-107.

16. Ali Khomsan. Teknik pengukuran pengetahuan. Bogor: Institut Pertanian Bogor. 2000. p.30-35.

17. Saifuddin Azwar. Sikap manusia teori dan pengukurannya. Yogyakarta: Pustaka Pelajar. 2008. p. 156

18. Soekidjo Notoatmodjo. Ilmu perilaku kesehatan. Jakarta: Rineka Cipta. 2010. p.27-30,76

19. Susilawati. Hubungan pengetahuan dan sikap dengan kepatuhan mengkonsumsi tablet besi folat pada ibu hamil dengan kejadian anemia gravidarum di Puskesmas Jabon Jombang. [Tesis]. Surakarta: Universitas Sebelas Maret Surakarta. 2011.

20. M. Nur Dewi Kartikasari. Hubungan antara pengetahuan dan sikap tentang anemia dengan keteraturan mengkonsumsi Fe pada ibu hamil di BPS Sri Lumintu Surakarta. [Tesis]. Surakarta: Universitas Sebelas Maret. 2010.

21. Nofa Sofianti. Studi motivasi dan perilaku dalam memelihara kesehatan selama kehamilan di Kabupaten Asahan. [Tesis]. Bogor: IPB. 2002.

22. Marlia P, Akhmadi, Wenny AN. Analisis faktorfaktor yang mempengaruhi ketidakpatuhan ibu hamil dalam mengkonsumsi tablet besi folat. JIK Vol.01/No.2/Mei/2006.

23. Thirukkanesh S, Zahara AM. Compliance to vitamin and mineral supplementation among preagnant women in urban and rural areas in Malaysia. Pakistan Journal of Nutrition 2010; 9(8): 744-750.

24. Marissa Indreswari, Hardinsyah. Hubungan antara intensitas pemeriksaan kehamilan, fasilitas pelayanan kesehatan dan konsumsi tablet besi dengan tingkat keluhan selama kehamilan. Jurnal Gizi dan Pangan 2008; 2(1): 12-21.

25. Lutsey PL, David D. Iron supplementation compliance among pregnant women in Bicol, Philippines. Public Health Nutrition 2007; 11(1), 76-82.

26. James LG. Advanced Nutrition and Human Metabolism, 4th Edition. USA:Wadsworth. 2005. p.422 
